\title{
Social Entrepreneurship from a Chronological Approach: A Path for Change
}

\author{
Virginia Simón-Moya ${ }^{1}$, María Rodríguez-García ${ }^{2}$ \\ Universitat de València, Valencia, Spain
}

\begin{abstract}
Social entrepreneurship represents a shift in paradigm, from an economic perspective focused on profit gains, to a broader meaning of value creation, including social welfare in its mission. In this line, social entrepreneurs are supposed to be the actors of change towards a more equally distributed society, in the fostering of social equilibrium. This research shows a how a typology of social entrepreneurship previously highlighted by academia can be understood through the exemplification of a real-life case. Through the case study of a Spanish scientist, social entrepreneurship phenomenon is seen as process consisting of three stages, bricoleur, constructionist and engineer. Thus, instead of understanding social entrepreneurship as a phenomenon that can be classified in different categories, it can be viewed as a chronology of three different phases. These phases are associated to different points of the professional career of the entrepreneur. Therefore, the unit of analysis is the individual, namely, Dr. Mateo. The first stage -social bricolage- is characterized by the scarcity of resources. Contrarily, a greater dimension and influence of the social change represents the main feature of the latest stages. Future research avenues should incorporate other units of analysis, complementary to the one presented in this study, in order to get a wider understanding of the reality.
\end{abstract}

Keywords: social entrepreneurship, social bricolage, social constructionism, social engineer.

\section{Introduction}

The phenomenon of social entrepreneurship has increased its interest in academia and scientific literature in recent years. However, its rise has not occurred in isolation, but rather it has been the demands of the global economic environment that have fostered new forms of entrepreneurship from a practical point of view. The economic actors that have traditionally been responsible for offering a solution to society, in the form of products and services, have certain limitations. In this sense, social entrepreneurship is presented as a tool to address these problems that are uncovered by traditional agents. Therefore, the study of social entrepreneurship is based on the assumption of the volatility, uncertainty, ambiguity and complexity of the current economic environment (Di Domenico et al., 2010).

From the individual point of view, the main agent is the social entrepreneur, who aims to contribute positively to society, and offer a solution to the local community they are targeting (Barendsen \& Gardner, 2004). In short, based on the premise of the entrepreneurial 
phenomenon, the dynamics lie in offering an innovative solution to a permanent problem $(\mathrm{Hu}$ \& Pang, 2013).

Social entrepreneurship can be studied from different points of view and methodologies. More specifically, the unit of analysis can be the level of the individual (social entrepreneur), the meso level (the venture), and the macroeconomic level (context) (Gartner, 1985). In addition to these conventional units of analysis, there is the chrono analysis, which allows us to evaluate and analyze a particular phenomenon over a specific period of time. This study has considered the combination of a stable and robust theoretical framework and the application of this framework to a particular case. At the same time, we have studied how social entrepreneurship has changed in form and content over time, being associated in each spatio-temporal unit with a different stage of the model of social entrepreneurship Zahra et al., (2009). This study responds to the call to analyze and investigate in depth the heterogeneity of the phenomenon of social entrepreneurship. This is so, since these are ventures that originate at the local level. Analyzing the motivations (intrinsic and extrinsic), as well as the consequences derived from the particular venture are a relevant object of study for the academy. In this way, new theories can be inferred to support the observation of reality. In short, through our research on social entrepreneurship we have conducted a combination of a micro-level (individual) study and a chronos perspective. That is, how the social entrepreneur evolves over time, depending on the stage of the venture. To support the theoretical foundation, we have based ourselves on the case of Pilar Mateo, $\mathrm{PhD}$ in Chemistry from the University of Valencia, who is considered a social entrepreneur and her case responds to the theoretical framework established by Zahra. Therefore, in this study we analyze the dimensions of social bricolage, social constructionist and social engineer (Zahra et al., 2009a) from a practical perspective, taking the example of Dr. Mateo as a reference

The structure of the paper is as follows: Following this introduction, the theoretical framework is presented. In this part, Zahra's model (2009) is mainly discussed. The methodology section explains the case study conducted with the social entrepreneur, and finally the results section expresses the codification of the information obtained in the interview. Finally, the conclusions and discussions section highlights the importance of further research on the heterogeneity of social ventures, combining different units of analysis.

\section{Theoretical Framework}

Entrepreneurship, as a way to generate value comprehends a multitude of realities. One of the main institutions dedicated to the study of startups is the Global Entrepreneurship Monitor (GEM). GEM makes a great work of compilation of these realities. Through the annual, the special topics and the national reports, academia can understand what the phenomenon of entrepreneurship adds to the current society and how the current society shapes entrepreneurship. In this way, GEM classifies the different contexts that frame entrepreneurship and how these contexts affect the type of entrepreneurship. And conversely, GEM also analyzes what the different types of entrepreneurs are and how they can affect the context. 
GEM considers three types of countries: factor-driven, efficiency-driven and innovationdriven. Each one of these types of countries involves a set of characteristics in economic and social terms. Each context promotes entrepreneurship in a different way.

Secondly, regarding the issue of the type of entrepreneurship and how it affects the context. GEM makes some distinctions. Thus, we can talk about a generic approach of entrepreneurship, in which all categories and realities of entrepreneurs fit or we can talk about different categories. These categories include family entrepreneurs (Kelley et al., 2020); senior entrepreneurship (Schott et al., 2017); necessity-driven or opportunity-driven entrepreneurship (Bosma et al., 2021), etc. As told, each one of these categories of entrepreneurship presents a set of characteristics regarding the venture created and his/her entrepreneur. And further, each one of the categories has something to offer to the context where it develops. The category considered in this study, meaning social entrepreneurship, is one of the most analyzed approach by the GEM, but also by academia (Battilana \& Dorado, 2010; Bosma et al., 2015; Chabrak et al., 2020; Di Domenico et al., 2010; Dorado, 2005).

Regarding the idiosyncrasy of social entrepreneurs, academia is doing a great effort to know how social entrepreneurs are. Regarding this issue, it seems that social entrepreneurs present higher levels of compassion than the rest of the population, what promotes a more integrative thinking and a more empathic behavior (Miller et al., 2012). The integrative thinking and the empathic behavior generate a type of entrepreneurship that adds a great value to society.

The value added to the context in which social entrepreneurship operates is a great field of research. The reason lies in the fact that the traditional entrepreneurship, that is, the creation of ventures with an economic purpose, can measure its performance in financial terms. In other words, companies have financial indicators that allow to measure if the purposes of the company are being met. However, for a social entrepreneur, it is difficult to know whether the purposes of the venture are achieved or not. The financial terms in which traditional ventures' performance are measured cannot be applied to social entrepreneurship because creating economic value for owners or shareholders is not the objective of social ventures. Thus, for a social entrepreneur, the value that his/her venture generates in society is the measure of success (Santos, 2012).

\section{1. Typology of social entrepreneurs}

Depending on the source of the research, social entrepreneurship and its main actor, the entrepreneur, can be defined in a different way. Nevertheless, though the way of defining social entrepreneurship differs, most of the studies highlight the importance of the value generated by social entrepreneurship. This value relates to the social change that this type of entrepreneurship has the purpose to achieve. In this way, Martin and Osberg (2007) define social entrepreneurs as the individuals that identify a stable but unjust equilibrium, see the opportunity to change it and promote a new and fair equilibrium. Accordingly, social entrepreneurship does not imply the constitution of an isolated venture "but on the appropriation and replication of the model and the spawning of a host of other related businesses" (Martin \& Osberg, 2007: 34). Associated with this, each type of social venture will have the potential to create a little or a great change. The scalability of the change is the result of the value generated to the society (Zahra et al., 2009). Depending on this, the 
typology of the social venture and its entrepreneur will differ. Zahra et al. (2009) defines social entrepreneurs in base to three groups: the social bricoleurs, the social constructionists and the social engineers. Although there are significant differences in each one of the groups, one of the most important distinctions remains in the size of the change generated.

Regarding the first category of social entrepreneur, the concept of social bricoleur has to do with the notion of equifinality. In management terms, this can be defined as the divergence of ways to achieve the same result. The study by Garud and Karnoe (2003) exemplifies the concept in the case of the wind turbine technology in Denmark and USA. The study shows how the collaborative networking, the involvement of the diversity of actors in the value chain and the search for incremental change can lead to a greater performance in technological terms than a search for a radical change and a great investment. In Baker and Nelson's (2005: 333) words "making do by applying combinations of resources at hand to new problems and opportunities". This definition, when applied to social entrepreneurship, acquires a major importance. This is due to the fact that social entrepreneurship usually operates in contexts with great resource scarcity (Di Domenico et al., 2010).

In this way, social bricolage applied to social entrepreneurship is related to the example of the wind turbines by Garud and Karnoe (2003). In this study, the search for an incremental change instead of a breakthrough is one of the keys for the greater results of the Danish industry. In the same way, social bricolage promotes a change motivated by the solution of a local need (Zahra et al., 2009). In this case, the baseline is the knowledge of the entrepreneur for recognizing the need and its possible solution.

The second typology of entrepreneur is called constructionist. The inspiration of Zahra et al. (2009) to conceptualize this entrepreneur comes from Kirzner (1973) and his alertness. The social constructionist is born as an individual who tries to fill the gaps that other institutions have not covered. The alertness of this type of entrepreneurs is the more useful resource. In this case, this alertness is addressed to discover the gaps and solve them. As said previously, the scalability is greater than the one of social bricoleurs. Thus, it needs more resources. That is why, social constructionists have the ability to network with other ventures in order to achieve more resources.

Finally, social engineers are motivated by a bigger change, not in extension but in deepness. For social constructionists, the change is not just focused on a local need or in a gap left by other institutions, the change should involve something more. The shift should be done in behavior paradigms, the figure of reference for Zahra et al. (2009) is Schumpeter. According to the authors, social engineers' work consists on the "[c] reation of newer, more effective social systems designed to replace existing ones when they are ill-suited to address significant social needs" (Zahra et al., 2009: 523). That is, what the authors define as social engineer is related to institutional entrepreneurship (Hardy \& Maguire, 2008). That is to say, these entrepreneurs try to carry out a change in the institutions that break with isomorphic practices and the taken-for-grantedness (DiMaggio \& Powell, 1983; Elam et al., 2019; Greenwood et al., 2002; Greenwood \& Hinings, 1996; Hardy \& Maguire, 2008).

The typology by Zahra et al. (2009) represents a diversity of social entrepreneurs. Although each one of the social entrepreneurs represents a different type, the three of them have 
similarities. In fact, the authors base the three categories in different works. Social bricoleurs are based on the irregularity of information highlighted by Hayek (1945), social constructionists on alertness (Kirzner, 1973), and social engineers on the creative destruction by Schumpeter (1942). All of these characteristics are related to the opportunity discovery and creation in order to accomplish a change (see figure 1).

Figure 1. Three paths for change

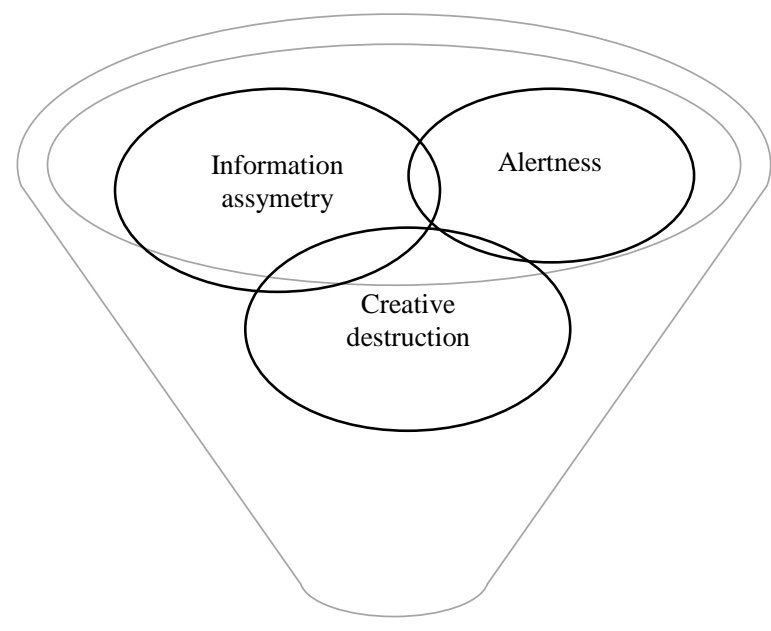

PATHS FOR CHANGE

\section{Methodology}

This research study follows a qualitative methodology. Specifically, the tool that has allowed us to obtain the necessary information to subsequently infer our results has been the case study (Yin, 1994). For this purpose, the fundamental source of information on which our study revolves around has been an interview arranged with Dr. Mateo. However, this information has been triangulated with secondary sources of information, such as documentaries on her venture, books and scientific articles.

Through the time-series analysis, we have been able to order and classify all the sources of information in chronological order, through which the results obtained have been structured. This analysis has allowed us to know how Pilar's educational background was a trigger in her professional career. In the same way, it helps us to build causal relationships in her career. In short, it helps us to understand the intrinsic and extrinsic motivations of the social entrepreneur, and the consequences on the immediate community and the global environment (in more advanced stages). In this temporal space, we have identified three different phases, 
which are characterized by their uniqueness and particular conditions. The following section presents a table with the main results obtained.

\section{Results}

Table 1 includes the theoretical foundations underlying the Zahra model (explained in the theoretical framework section) and its exemplification in the case of Dr. Mateo.

In the social bricolage stage, which is identified with the beginnings of the social entrepreneurship phenomenon (Zahra et al., 2009a), Pilar combined the resources he had in her environment to offer different solutions to local problems. Some examples were the antislip water-based traffic paints in a locality close to hers, and intumescent paints. The feeling of belonging, knowledge and empathy with the environment represent a starting point in the creation of innovative solutions that try to give an answer to a problem that had been ongoing until now. One of Pilar's inventions (which eventually became the main one), consists of a paint alternative to conventional insecticides. Its technology is summarized in the polymeric microencapsulation, which allows a slower release of the insecticide. In this way, the persistence of the product on the surface is greater, and the toxicity is lower. Dr. Mateo considered this option to be a very viable solution for Spanish hospitals, and that it could also be exported to other European countries such as Germany. However, she never thought that her painting could save lives on the other side of the world. Through different connections with doctors and the Latin American high spheres, she was able to realize that her inventions could be a solution for the disease that kills a considerable percentage of the South American population: Chagas disease. The eradication of this disease as well as the tools to deal with it are scarce on the part of institutions and local governments. Therefore, social entrepreneurship is presented as a viable solution that surpasses the limitations of the rest of the market players.

In the objective promoted by Pilar to eradicate the social and economic poverty of the indigenous tribes, the social entrepreneur requests the collaboration of the institutions to address it in a more concise way. Based on the negative responses that sometimes originate, Pilar decides to consolidate organizations such as the Movement of Indigenous Women of the World (MOVIM), which fight and promote a revolutionary and different concept of social balance than the one established so far.

Table 1: Zahra's social entrepreneurship model applied to Dr. Mateo's case 


\section{3rd International Academic Conference on MANAGEMENT and ECONOMICS}

\begin{tabular}{|c|c|c|c|}
\hline & Social Bricoleur & $\begin{array}{l}\text { - The local needs are placed at the } \\
\text { core. } \\
\text { The resources available to the social } \\
\text { entrepreneur are limited. } \\
\text { - The scope is local but an initial } \\
\text { trend is shown in the achievement of } \\
\text { "social equilibrium". }\end{array}$ & $\begin{array}{l}\text { - Pilar created different products as a } \\
\text { solution to local problems. } \\
\text { - The resources she had available were } \\
\text { family-owned resources. } \\
\text { - She indicated the direction towards "Social } \\
\text { equilibrium" by the elimination of insects } \\
\text { with her products. }\end{array}$ \\
\hline 3. & Social Engineer & $\begin{array}{l}\text { - The primary purpose is to achieve a } \\
\text { social change at institutional level } \\
\text { Old dynamics should be replaced } \\
\text { with new values and heuristics. } \\
\text { Overhaul of the phenomenon of } \\
\text { "social equilibrium" and } \\
\text { consolidation of a new one. }\end{array}$ & $\begin{array}{l}\text { The problem behind the illnesses } \\
\text { goes beyond economic issues. } \\
\text { The purpose of Dr. Mateo is to } \\
\text { include institutions as mechanisms against } \\
\text { poverty. } \\
\text { - Dr. Mateo boosted movements } \\
\text { and organizations such as MOVIM. }\end{array}$ \\
\hline
\end{tabular}

Source: Own elaboration

\section{Conclusion}

The current research shows that entrepreneurship is a phenomenon that comprehends a diversity of realities. These realities are materialized in the different types of entrepreneurs. One of these categories is the social entrepreneurship. Social entrepreneurship, at the same time, can also be classified according to different typologies. One of the main analyses that try to do a clear distinction on the social entrepreneurship phenomenon is the research carried out by Zahra et al. (2009). This study divides social entrepreneurs into three groups: bricoleurs, constructionists and engineers. Although the different groups are supposed to contain different individuals, the research of our analysis shows that bricoleurs, constructionists and engineers characteristics can be found in the same individual, but in different phases along their career. One example of this process is the case of Dr. Mateo. 
The social innovation carried out by Dr. Mateo shows that while the polymeric microencapsulation can be linked to a solution of a local need, the intend of changing the context corresponds to the approach of social constructionist and engineer. In fact, our case shows that the typology of social entrepreneurs can be seen as a time-series in which the entrepreneur passes from one stage to another in a process of social entrepreneurship maturation.

The last actions of the Dr. Mateo in favor of indigenous women through the creation of MOMIM tries to change a global paradigm. The role of the woman in the indigenous world is the baseline for the organization. That is, the scalability and deepness of the change is greater than the one performed with the creation of the paint. Although this study contributes to the literature of social entrepreneurship, it is subject to some limitations, which could be overcome in future research avenues. Specifically, the study is addressed from an individual unit of analysis. It would be interesting to triangulate the conclusions with information provided at a meso or company level. Additionally, we have focused out study on the characteristics of each phase (bricoleur, constructionist and engineer). However, we invite researchers to focus on the transition (how, why...) of one stage to another.

\section{Acknowledgment}

This paper is one of the outputs obtained from the research carried out with the social entrepreneur Pilar Mateo, PhD in Chemistry at the University of Valencia. This paper is a first draft of the book in review process authored by Simón-Moya, V. and Rodríguez-García, M, called "THE EMERGENCE OF SOCIAL ENTREPRENEURSHIP: INDIVIDUALS AND SOCIAL VENTURES AS AGENTS OF CHANGE".

\section{References}

For each work shown in the list of references must be a reference in the text. All citations in the text and all references must meet APA styles (American Psychological Association $7^{\text {th }}$ edition - more information http://www.apastyle.org/).

Baker, T., \& Nelson, R. E. (2005). Creating something from nothing: Resource construction through entrepreneurial bricolage. Administrative Science Quarterly, 50(3), 329-366.

Barendsen, L., \& Gardner, H. (2004). Is the social entrepreneur a new type of leader? Leader to Leader, 2004(34), 43-50.

Battilana, J., \& Dorado, S. (2010). Building sustainable hybrid organizations: The case of commercial microfinance organizations. Academy of Management Journal, 53(6), 14191440 . 
Bosma, N., Hill, S., Ionescu-Somers, A., Kelley, D., Guerrero, M., \& Schott, T. (2021). GEM 2020/2021 Global Report.

Bosma, N., Schøtt, T., Terjesen, S., \& Kew, P. (2015). Global Entrepreneurship Monitor Special Topic Report: Social Entrepreneurship. Global Entrepreneurship Monitor, 1-44. www. gemconsortium.org

Chabrak, N., Thomas, L., Bascausoglu-Moreau, E., \& Bouhaddioui, C. (2020). 2019 / 2020 gem uae.

Di Domenico, M., Haugh, H., \& Tracey, P. (2010). Social bricolage: Theorizing social value creation in social enterprises. Entrepreneurship Theory and Practice, 34(4), 681-703.

DiMaggio, P. J., \& Powell, W. W. (1983). The Iron Cage Revisited: Institutional Isomorphism and Collective Rationality in Organizational Fields. American Sociological Review, 48(2), 147-160.

Dorado, S. (2005). Institutional entrepreneurship, partaking, and convening. Organization Studies, 26(3), 385-414.

Elam, A. B., Brush, C. G., Greene, P. G., Baumer, B., Dean, M., Heavlow, R., Babson College, Smith College, \& Global Entrepreneurship Research Association. (2019). Global Entrepreneurship Monitor: 2018/2019 Women's Entrepreneurship Report. In Global http://www.gemconsortium.org/report/50012\%0Ahttps://www.gemconsortium.org/report /gem-20182019-womens-entrepreneurship-report

Gartner, W. B. (1985). A conceptual framework for describing the phenomenon of new venture creation. Academy of Management Review, 10(4), 696-706.

Garud, R., \& Karnøe, P. (2003). Bricolage versus breakthrough: distributed and embedded agency in technology entrepreneurship. Research Policy, 32(2), 277-300.

Greenwood, R., \& Hinings, C. R. (1996). Understanding Radical Organizational Change: Bringing together the Old and the New Institutionalism. Academy of Management Review ,21(4), 1022-1054.

Greenwood, R., Suddaby, R., \& Hinings, C. R. (2002). Theorizing Change: The Role of Professional Associations in the Transformation of Institutionalized Fields. Academy of Management Journal, 45(1), 58-80.

Hardy, C., \& Maguire, S. (2008). Intitutional Entrepreneurship. In R. Greenwood, C. Oliver, K. Sahlin, \& R. Suddaby (Eds.), The Sage Handbook of Organizational Institutionalism (pp. 198-217). Sage.

Hayek, F. A. (1945). The Use of knowledge in Society. American Economic Review, 91(1), 519-530.

Hu, Y., \& Pang, X. (2013). Social entrepreneurial orientation and performance of nonprofit organizations: an empirical study in China. Journal of Applied Sciences, 13(19), 39893994. 
Kelley, D. J., Gartner, W. B., \& Allen, M. (2020). 2019/2020 Family Entrepreneurship Report Global Entrepreneurship Monitor.

Kirzner, I. M. (1973). Competition and entrepreneurship. University of Chicago press.

Martin, R., \& Osberg, S. (2007). Social Entrepreneurship: The Case for definition. Stanford Social Innovation Review, Spring, 1-18.

Miller, T. L., Grimes, M. G., Mcmullen, J. S., \& Vogus, T. J. (2012). Venturing for others with heart and head: How compassion encourages social entrepreneurship. Academy of Management Review, 37(4), 616-640.

Santos, F. M. (2012). A Positive Theory of Social Entrepreneurship. Journal of Business Ethics, 111(3), 335-351.

Schott, T., Rogoff, E., Herrington, M., \& Kew, P. (2017). Special Topic Report 2016-2017 Senior Entrepreneurship. Global Entrepreneurship Monitor. http://gemconsortium.org/report

Schumpeter, J. A. (1942). Socialism, capitalism and democracy. Harper and Brothers.

Yin, R. K. (1994). Case Study Research. Design and Methods. Sage Publications.

Zahra, S. A., Gedajlovic, E., Neubaum, D. O., \& Shulman, J. M. (2009a). A typology of social entrepreneurs: Motives, search processes and ethical challenges. Journal of Business Venturing, 24(5), 519-532. 